\title{
Determination of the Factors Preventing Students of the Faculty of Sports Sciences from Participating in Recreational Activities: Ondokuz Mayıs University Sample
}

\author{
Mehmet ÇEBi ${ }^{1}$ Gül ÇAVUŞOĞLU ${ }^{2}$ Şaban ÜNVER ${ }^{3}$ İzzet ISLAMOĞLU ${ }^{4}$ Kürşat ACAR $^{5}$ \\ ${ }^{1234}$ Ondokuz Mayıs University Yaşar Doğu Faculty of Sports Sciences, SAMSUN \\ ${ }^{5}$ Sinop University Faculty of Sports Sciences, SiNOP \\ ${ }^{1}$ mehmet.cebi@omu.edu.tr \\ ²gulcavusoglum@hotmail.com \\ 3 saban.unver@omu.edu.tr \\ 4izzetislamoglu@gmail.com \\ 5kursatacar@windowslive.com
}

\begin{abstract}
The purpose of this study is to examine the factors which prevent the students of Faculty of Sport Sciences from participating in recreational activities in terms of some variables.

A total of 275 (183 men, 92 women) randomly chosen students studying at Yaşar Doğu Faculty of Sport Sciences participated in the study voluntarily. "Leisure Constraints Questionnaire" developed by Alexandris and Carroll (1997) adapted to Turkish by Karaküçük and Gürbüz (2007) was used as the data collection tool. The data obtained were analyzed with SPSS 21 package program. Kolmogrov test was used to find out whether the data were normally distributed and the data were found to be normally distributed. The data were analyzed with frequency analysis, $t$ test and Anova test in independent samples and the Bonferroni test was used to analyze the difference between groups.

The factors which prevented students from participating in recreational activities showed significant differences in "individual psychological" subscale and total scores in terms of the variable of age and in "facilities/services and accessibility" subscale in terms of gender $(p<0,05)$. In terms of the difference in the age variable, participation in recreational activities increased as age increased. In terms of gender, women were seen to participate less in recreational activities when compared with men.
\end{abstract}

The results of the study showed that the students of the Faculty of Sport Sciences did not have difficulties in participating in recreational activities; however, women were found to participate less than men. In order to increase women's participation, informative activities, activities for women and interesting activities for women should be made more attractive.

Key Words: Recreation, Sports Sciences, Campus

\section{Academic Discipline And Sub-Disciplines}

Education

\section{SUBJECT CLASSIFICATION}

Social Science

\section{TYPE (METHOD/APPROACH)}

Survey

\section{INTRODUCTION}

Students in higher education institutions, which have a very important place and value in our lives, have an important place within our population that has a young structure. In addition to this, they are the never ending potential and security of our future with their sensitive and dynamic structure. Thus, issues about students, issues about what students do in their free time are the common issues and problems of all higher education institutions (Mutlutürk, 1991). University is not a period in which individuals are only interested in lessons, fully developing themselves. For a great number of individuals, university is important in terms of academic and socio-cultural development. At the same time, recreational activities have a positive effect on a great number of areas of human life (job satisfaction, life satisfaction, family life, etc.) (Aslan, 2009 Huang and Carleton, 2003).

Today, the effects of recreational activities in which young people and children participate on social, physical, mental and emotional development have been the subject of many researches. Individuals meet with various obstacles in participating in these activities or in continuing these activities (Crawford, 1987). A great number of studies in different areas have shown that recreational activities make positive effects on the process of urbanization and on personal and social health. Despite these positive contributions of participation to recreational activities, it has been found that individuals do not participate in such activities which are important for them with various reasons or that they cannot participate due to

${ }^{2}$ Corresponding author: gulcavusoglum@hotmail.com

\section{$2232 \mid$ P a g e}

Nove mber 2016 
various obstacles (Karaküçük and Gürbüz, 2007). It is possible to talk about many personal, social and economic factors which prevent the efficient use of time (Karaküçük, 2005). Each student who spends time in classes, laboratories or desks today needs to participate in recreational activities. For this reason, universities' activity programs should create opportunities for recreation and resting and should enable students to get rid of the intensity caused by modern life and school studies. Required efforts, planning and programming should be done for this (Kılbaş, 2001).

Although the participation of university students studying in Turkish universities in spare time activities has increased recently with the development of campuses and with the efforts of managements, it can be seen that they are still not enough in many universities (Balcı, 2003). Creating areas for recreational activities by increasing universities' investments, developing the opportunities to do sports and enabling young people to know and love the sports environment better by supporting the socialization process of young people (Voigt, 1998) will make a great contribution to young people's assessing free time activities with constructive activities. Within this context, the objective of this study is to find out the reasons that prevent young people from participating into recreational activities.

\section{MATERIAL AND METHOD}

A total of 275 (183 male, 92 female) who were studying at Yaşar Doğu Faculty of Sports Sciences and who were chosen randomly participated in the study voluntarily. The data were obtained through a questionnaire applied to students by the researcher. Two different forms, a personal information form and "Leisure Constraints Questionnaire", were used in the study.

"Leisure Constraints Questionnaire" developed by Alexandris and Carroll (1997) and adapted to Turkish by Karaküçük and Gürbüz (2007) which assesses the factors that can constraint university students from participating recreational activities was used in the study. "Leisure Constraints Questionnaire" is a 27-item questionnaire that assesses the factors that prevent participation to recreational activities and it consists of 6 subscales. The first subscale (individual psychological) consists of items 1,2,3 and 4; the second subscale (lack of information) consists of items 5,6,7 and 8; the third subscale (facilities/services and accessibility) consists of items 10,11,12,13,14,15,16 and 17; the fourth subscale (lack of partners) consists of items 18, 19 and 20; the fifth subscale (time) consists of items 21,22,23 and 24; the second subscale (lack of interests) consists of items 25,26 and 27.

SPSS 21 package program was used to analyze the data obtained. Kolmogorov-Smirnov test was used to test whether the data were normally distributed and they were found to be normally distributed. The data were analyzed by frequency analysis independent samples were analyzed by t test and Anova test and the difference between groups was analyzed with Bonferoni test.

\section{FINDINGS}

In this section, the data obtained from the students of the Faculty of Sports were analyzed.

Table 1. Students' basic statistics and ANOVA test results of sub dimensions in terms of the variable of age

\begin{tabular}{|c|c|c|c|c|c|c|}
\hline Subscales & Age & $\mathbf{N}$ & Mean & SD & $\mathbf{F}$ & $\mathbf{P}$ \\
\hline \multirow{4}{*}{$\begin{array}{c}\text { Individual } \\
\text { psychological }\end{array}$} & $17-19(1)$ & 33 & 11,15 & 1,872 & \multirow{4}{*}{6,647} & \multirow{4}{*}{$\begin{array}{l}, 000 \\
1>3 \\
2>3\end{array}$} \\
\hline & $20-22(2)$ & 181 & 11,44 & 2,457 & & \\
\hline & $23-25$ (3) & 51 & 9,62 & 3,174 & & \\
\hline & $26+(4)$ & 10 & 10,60 & 3,657 & & \\
\hline \multirow{4}{*}{$\begin{array}{c}\text { Lack of } \\
\text { information }\end{array}$} & 17-19(1) & 33 & 14,63 & 2,945 & \multirow{4}{*}{2,225} & \multirow{4}{*}{0,86} \\
\hline & $20-22(2)$ & 181 & 14,92 & 2,944 & & \\
\hline & $23-25$ (3) & 51 & 13,68 & 4,259 & & \\
\hline & $26+(4)$ & 10 & 13,60 & 4,141 & & \\
\hline \multirow{4}{*}{$\begin{array}{l}\text { Facilities/services } \\
\text { and accessibility }\end{array}$} & $17-19(1)$ & 33 & 23,63 & 3,855 & \multirow{4}{*}{2,253} & \multirow{4}{*}{0,83} \\
\hline & $20-22(2)$ & 181 & 24,25 & 3,877 & & \\
\hline & $23-25$ (3) & 51 & 22,54 & 5,017 & & \\
\hline & $26+(4)$ & 10 & 24,20 & 5,902 & & \\
\hline \multirow{4}{*}{ Lack of partners } & $17-19(1)$ & 33 & 8,00 & 1,677 & \multirow{4}{*}{0,674} & \multirow{4}{*}{0,568} \\
\hline & $20-22$ (2) & 181 & 7,59 & 2,238 & & \\
\hline & $23-25$ (3) & 51 & 7,37 & 2,537 & & \\
\hline & $26+(4)$ & 10 & 8,10 & 2,685 & & \\
\hline
\end{tabular}


JOURNAL OF SOCIAL SCIENCES RESEARCH

\begin{tabular}{|c|c|c|c|c|c|c|}
\hline \multirow{4}{*}{ Time } & $17-19(1)$ & 33 & 10,96 & 2,007 & \multirow{4}{*}{1,705} & \multirow{4}{*}{0,166} \\
\hline & $20-22(2)$ & 181 & 11,55 & 2,381 & & \\
\hline & $23-25(3)$ & 51 & 11,05 & 2,485 & & \\
\hline & $26+(4)$ & 10 & 12,50 & 1,957 & & \\
\hline \multirow{4}{*}{ Lack of interests } & $17-19(1)$ & 33 & 7,33 & 1,831 & \multirow{4}{*}{2,081} & \multirow{4}{*}{0,103} \\
\hline & $20-22(2)$ & 181 & 7,71 & 1,973 & & \\
\hline & $23-25(3)$ & 51 & 6,94 & 2,548 & & \\
\hline & $26+(4)$ & 10 & 7,00 & 2,624 & & \\
\hline \multirow{4}{*}{ Total scores } & $17-19(1)$ & 33 & 75,72 & 8,679 & \multirow{4}{*}{3,891} & \multirow{4}{*}{$\begin{array}{c}0,010 \\
2>3\end{array}$} \\
\hline & $20-22(2)$ & 181 & 77,48 & 10,381 & & \\
\hline & $23-25(3)$ & 51 & 71,23 & 15,450 & & \\
\hline & $26+(4)$ & 10 & 76,00 & 16,485 & & \\
\hline
\end{tabular}

When students' analysis (ANOVA) results of sub dimensions in terms of the variable of age were analyzed in Table 1, it was found that students' "individual psychological" sub dimension results showed a significant difference in terms of age $[F=6,647 ; p<0,05]$. Bonferoni test results, which was conducted to find out between which groups there were differences, showed significant differences between the scores of students aged 17-19 and 23-25 and between the scores of students aged 20-22 and 23-25. "Individual psychological" sub dimension scores of the students aged 20-22 were found to be higher than the scores of students in other age groups.

No statistically significant difference was found between all sub dimensions of students except "individual psychological" sub dimension in terms of age. There are no differences in views between age groups in terms of these sub dimensions.

Significant difference was found between total score from the scale and age groups based on students' views $[F=3,891$; $\mathrm{p}<0,05]$. According to Bonferoni test results, which was conducted to find out which group created the difference, it was found that students aged 23-25 think that there are less constraints on their leisure time when compared with students aged 20-22.

Table 2. Students' basic statistics and T-test results of sub dimensions in terms of the variable of gender

\begin{tabular}{|c|c|c|c|c|c|c|}
\hline Subscales & Gender & $\mathbf{N}$ & Mean & SD & $\mathbf{T}$ & $\mathbf{P}$ \\
\hline \multirow{2}{*}{ Individual psychological } & Male & 183 & 11,08 & 2,669 & \multirow{2}{*}{0,383} & \multirow{2}{*}{0,859} \\
\hline & Female & 92 & 10,95 & 2,692 & & \\
\hline \multirow{2}{*}{ Lack of information } & Male & 183 & 14,61 & 3,199 & \multirow{2}{*}{0,008} & \multirow{2}{*}{0,651} \\
\hline & Female & 92 & 14,60 & 3,489 & & \\
\hline \multirow{2}{*}{$\begin{array}{l}\text { Facilities/services and } \\
\text { accessibility }\end{array}$} & Male & 183 & 23,56 & 4,549 & \multirow{2}{*}{$-1,633$} & \multirow{2}{*}{0,009} \\
\hline & Female & 92 & 24,44 & 3,410 & & \\
\hline \multirow{2}{*}{ Lack of partners } & Male & 183 & 7,82 & 2,246 & \multirow{2}{*}{2,126} & \multirow{2}{*}{0,962} \\
\hline & Female & 92 & 7,21 & 2,217 & & \\
\hline \multirow{2}{*}{ Time } & Male & 183 & 11,25 & 2,368 & \multirow{2}{*}{$-1,676$} & \multirow{2}{*}{0,648} \\
\hline & Female & 92 & 11,76 & 2,307 & & \\
\hline \multirow{2}{*}{ Lack of interests } & Male & 183 & 7,48 & 2,135 & \multirow{2}{*}{0,191} & \multirow{2}{*}{0,511} \\
\hline & Female & 92 & 7,53 & 2,077 & & \\
\hline \multirow{2}{*}{ Total scores } & Male & 183 & 75,83 & 12,295 & \multirow{2}{*}{0,460} & \multirow{2}{*}{0,226} \\
\hline & Female & 92 & 76,52 & 10,590 & & \\
\hline
\end{tabular}

When the results of university students' sub dimensions based on the variable of gender were analyzed in Table 2, it was found that the scores of "facilities/services and accessibility" $[t=-1,633 ; p<0,05]$ sub dimension differed in terms of gender 
and the difference was thought to result from "female" students, the other sub dimension scores were not found to differ significantly in terms of "gender".

Table 3. Students' basic statistics and T-test results of sub dimensions in terms of the variable of the places to spend leisure time

\begin{tabular}{|c|c|c|c|c|c|c|}
\hline Subscales & $\begin{array}{l}\text { Places to spend } \\
\text { leisure time }\end{array}$ & $\mathbf{N}$ & Mean & SD & $\mathbf{T}$ & $\mathbf{P}$ \\
\hline \multirow{2}{*}{$\begin{array}{c}\text { Individual } \\
\text { psychological }\end{array}$} & On campus & 35 & 10,94 & 2,645 & \multirow{2}{*}{0,197} & \multirow{2}{*}{0,844} \\
\hline & Off campus & 239 & 11,03 & 2,668 & & \\
\hline \multirow{2}{*}{$\begin{array}{l}\text { Lack of } \\
\text { information }\end{array}$} & On campus & 35 & 14,22 & 3,299 & \multirow{2}{*}{0,699} & \multirow{2}{*}{0,485} \\
\hline & Off campus & 239 & 14,64 & 3,284 & & \\
\hline \multirow{2}{*}{$\begin{array}{l}\text { Facilities/services } \\
\text { and accessibility }\end{array}$} & On campus & 35 & 24,17 & 4,375 & \multirow{2}{*}{0,512} & \multirow{2}{*}{0,609} \\
\hline & Off campus & 239 & 23,78 & 4,176 & & \\
\hline \multirow{2}{*}{ Lack of partners } & On campus & 35 & 7,48 & 2,119 & \multirow{2}{*}{0,339} & \multirow{2}{*}{0,735} \\
\hline & Off campus & 239 & 7,62 & 2,260 & & \\
\hline \multirow{2}{*}{ Time } & On campus & 35 & 11,17 & 1,932 & \multirow{2}{*}{0,649} & \multirow{2}{*}{0,517} \\
\hline & Off campus & 239 & 11,44 & 2,407 & & \\
\hline \multirow{2}{*}{ Lack of interests } & On campus & 35 & 7,11 & 2,054 & \multirow{2}{*}{1,110} & \multirow{2}{*}{0,268} \\
\hline & Off campus & 239 & 7,53 & 2,103 & & \\
\hline \multirow{2}{*}{ Total scores } & On campus & 35 & 75,11 & 11,158 & \multirow{2}{*}{0,455} & \multirow{2}{*}{0,650} \\
\hline & Off campus & 239 & 76,07 & 11,691 & & \\
\hline
\end{tabular}

According to Table 3, when the results of all sub dimensions were analyzed in terms of the variable of the places to spend leisure time, no statistically significant difference was found $(p>0,05)$.

\section{DISCUSSION AND RESULTS}

The necessity and authenticity of putting leisure time to good use is a currently existing condition (Can, 2010). In their time that is left from their lessons and necessities, university students should make use of the concept of recreation and the activities included in this concept in order to get rid of their psychological problems, to socialize, to increase their culture and knowledge and to be healthy in terms of sports. By this means, they will be able to make use of the aforementioned positive effects and it will be easier for them to reach success in both their socio-cultural lives and in their professional lives (Kaba, 2009). Today, it is as important as their education for young people to participate in recreational activities. Thus, the objective of this study is to analyze the factors that prevent students of the Faculty of Sports Sciences from participating in leisure time activities in terms of various variables.

Torkildsen (2012) stated that age had a significant effect on participating in recreational activities but this effect changed according to the person doing the activity and the type of activity done. When the leisure time constraints of the students in our study were analyzed in terms of age, a significant difference was found in individual psychological sub dimension. This difference was found between students aged 17-19 and 23-25 and students aged 20-22 and 23-25. As well as studies that support the findings of our study (Pala and Dinç, 2013), there are also studies which have reached contrary results (Kunz and Graham, 1996; Alexandris and Carroll, 1997). It is estimated that the reasons which prevent students aged 17-19 and 20-22 are the fact that they do not have enough information about these activities and thus the thought that these activities can cause injuries or health problems. At the same time, aging can cause a person to get more experience in life and to have more self-confidence and thus to have more expectations in this direction.

Moccia (2000) stated that gender has a significant role in the preferences for leisure time activities. Different researchers have stated that gender is an important factor that restricts individual's leisure time activities (Demir and Demir, 2006; Alexandris and Carroll, 1997; Culp, 1998; Hudson, 2000). When university students' results of the sub dimensions of individual psychology, lack of information, facilities/services and accessibility, lack of partners, time, lack of interests were analyzed in terms of gender, it was found that "facilities/services and accessibility" scores differed significantly in terms of gender and the difference resulted from "female" students, while no statistically significant difference was found between female and male students in other sub dimensions. As a conclusion, it can be said that male students do not think that facilities/services and accessibility sub dimension is not a constraint in participating in recreational activities. Female students' viewing facilities/services and accessibility sub dimension as a constraint can be explained with the thoughts that they will feel under pressure in case of doing activities with men due to social structure and they will have more difficulties 
in accessing and using facilities when compared with men. Ergül (2008) stated that presence of sports facilities in the neighborhood students live is a factor that increases the possibility of doing sports. At the same time, it can be said that women's appearances can restrict the activities they participate in public facilities. Tolukan (2010) reported that there was statistically significant difference between male and female groups in terms of only lack of information sub dimension and that this difference resulted from women. In literature, there are a great number of studies which state that women are less inclined to recreational activities than men (Balcı, 2003; Karaküçük and Gürbüz, 2007; Balcı and ilhan, 2006).

As a conclusion, it can be seen that students of the Faculty of Sports Sciences do not have any difficulties in participating in recreational activities, only female students view the sub dimension of facilities/services and accessibility as a constraint in participating in recreational activities when compared with male students. Thus, it was concluded that female students are not given an effective environment in using their time well. In order to increase female students' participation, facilities should be developed and increased in number, instructive information should be presented in using leisure time activities well, students should be given the conscience to do sports and physical activities and activities special for women and activities that will attract women's attention more should be planned. While planning the activities, it is of great importance to make social and sportive organizations attractive and to organize such activities in every period in order to be able to make not only female students, but all students participate in leisure time activities. In addition, conducting studies in a way that they will include other university and faculty students will make important contributions in terms of generalizing the results.

\section{REFERENCES}

1. Alexandrıs, K. and Carroll, B. 1997. Demographic Differences İn The Perception Of Constraints On Recreational Sport Participation. Results From A Study İn Greece, Liesure Studies, 16, 107-125.

2. Aslan, N. 2009. An Examination Of Family Lesiure And Family Satisfactiom Among Traditional Turkish Families. Journal Of Leisure Research. 41 (2), 157-176.

3. Balcı, V. 2003. Ankara'daki Üniversite Öğrencilerinin Boş Zaman Etkinliklerine Katılımlarının Araştırılması. Milli Eğitim Dergisi, 158, 161-173.

4. Balcı, V. and İlhan, A. 2006. Türkiye'deki Üniversite Öğrencilerinin Rekreatif Etkinliklere Katılım Düzeylerinin Belirlenmesi. Spormetre Beden Eğitimi ve Spor Bilimleri Dergisi, 4(1), 11-18.

5. Can, S. 2010. Muğla Üniversitesi Eğitim Fakültesi İlköğretim Bölümü Öğrenci Ailelerinin Boş Zaman Faaliyetlerine Katılım Biçimlerinin Belirlenmesi. Kastamonu Eğitim Dergisi,18(3), 861-870

6. Crawford, D. W. and Godbey, G. 1987. Reconceptualizing Barriers To Family Leisure. Leisure Sciences, 9 (2): 119-127.

7. CULP, RH. 1998. Adolescent Girls and Outdoor Recreation: A Case Study Examing Constraints and Effective Programming. Journal of Leisure Research, 30(3), 356-379.

8. Demir, C. and Demir, N. 2006. Bireylerin boş zaman faaliyetlerine katılmalarını etkileyen faktörler ile cinsiyet arasındaki ilişki: Lisans oğrencilerine yönelik bir uygulama. Ege Üniversitesi. İktisadi ve İdari Bilimler Fakültesi, Ege Akademik Bakış Dergisi, 6(1), 36-48.

9. Ergül, O.K. 2008. Üniversite Gençliğinin Sportif Rekreasyon Etkinliklerine Yönelik İlgileri ve Katılma Düzeylerinin Belirlenmesi. Yüksek Lisans Tezi. Celal Bayar Üniversitesi, Sağlık Bilimleri Enstitüsü.

10. Huang, C. Y. and Carleton, B. 2003. The Relationships Among Leisure Participation, Leisure Satisfaction, And Life Satisfaction Of College Students İn Taiwan. Journal Of Exercise Science And Fitness, 1(2), 129-132.

11. Hudson, S. 2000. The Segmentation of Potential Tourists: Constraint Differences between Men and Women. Journal of Travel Research, 38(4), 363- 368.

12. Kaba, C.İ. 2009. Türkiye' deki Üniversitelerde Kampüs Rekreasyonunun Mevcut Durumu ve Kampus Rekreasyon Modellemesi. Marmara Üniversitesi, Sağlık Bilimleri Enstitüsü, Beden Eğitimi ve Spor Anabilim Dalı, Yüksek Lisans Tezi.

13. Karaküçük, S. 2005. Rekreasyon (Boş Zamanları Değerlendirme) "Kavram, Kapsam Ve Bir Araştırma (5. Baskı), Ankara: Gazi Kitabevi.

14. Karaküçük, S. and Gürbüz, B. 2007. Rekreasyon Ve Kent(Li)Leşme, Ankara: Gazi Kitabevi.

15. Kılbaş, S. 2001. Rekreasyon, Adana: Anaca Yayınları s.20.

16. Kunz, J.L. and Graham, K. 1996. Life course changes in alcohol consumption in leisure activities of men and women. Journal of Drug Issues, 26 (4): 805-827.

17. Moccia, F.D. 2000. Plannig Time: An Emergent European Practice. European Plannig Studies, 8(3), 367-376.

18. Mutlutürk, F. 1991. Yüksek Öğretim Gençliğinin Boş Zamanını Değerlendirme Aracı Olarak Spor. Dokuz Eylül Üniversitesi, Sosyal Bilimler Enstitüsü, İzmir.

19. Pala, F. and Dinç, S.C. 2013. Kamu Kurumlarında Görev Yapan Personelin Serbest Zaman Etkinliklerine Katılımını Engelleyen Faktörlerin Belirlenmesi. 2. Rekreasyon Araştırmaları Kongresi, Aydın, Turkey, 632-637.

20. Tolukan, E. 2010. Özel Yetenekle İlgili Bölümlerde Okuyan Üniversite Öğrencilerinin Rekreasyonel Aktivitelere Katılımlarına Engel Olabilecek Unsurların Belirlenmesi. Yüksek Lisans Tezi, Niğde Üniversitesi, Sosyal Bilimler Enstitüsü.

21. Torkildsen, G. 2012. Torkildsen's sport and leisure management. In: Taylor P, editor, Routledge: Oxon.

22. Voigt, D. 1998. Spor Sosyolojisi, (Çev: Ayse Atalay), Alkım Yayınları, İstanbul. 